\title{
Systematics of the Genus Polysiphonia Greville (Ceramiales, Rhodophyta) from Setse and Kyaikkhami Coastal Areas, Thanlwin River mouth, Myanmar
}

\author{
Jar San*, U. Soe-Htun
}

Department of Marine Science, Mawlamyine University, Myanmar

*Corresponding Author: Jar San, Department of Marine Science, Mawlamyine University, Myanmar; E-mail: jarsan.jarsan@ gmail.com

\begin{abstract}
Two species of the genus Polysiphonia Greville (Ceramiales, Rhodophyta) collected from Setse and Kyaikkhami coastal areas of Mon State, from June 2011 to March 2015, were identified as $P$. subtilissima Montagne and uncertain species as $P$. sp.1, mainly based on morphology of vegetative and reproductive structures. The plants are widely distributed in estuaries and salt marshes attached to substrata such as pneumatophores of trunks of mangroves trees and on other solid objects. In the present study, the plants of P. subtillissima Montagne were commonly found in the Kyaikkhami coastal areas while those of Polysiphonia sp. 1 were uniquely encountered in the Setse coastal areas. In addition, the comparison on main characteristics and some ecological notes of Polysiphonia spp. from Setse and Kyaikkhami coastal areas are provided.
\end{abstract}

Keywords: Distribution; Ecological notes; Kyaikkhami; Morphology; Polysiphonia subtilissima; P. sp. 1; Setse; Taxonomy

\section{Introduction}

The cosmopolitan genus Polysiphonia is widely distributed in most temperate and tropical waters of the world ${ }^{[1]}$. Recently, Guiry and Guiry ${ }^{[2]}$ recorded 119 species of Polysiphonia reported from various regions of world oceans. The genus Polysiphonia divided into four sub-genera, Pterosiphonia, Herposiphonia, Oligosiphonia and Polysiphonia. Among these, the last two sub-genera have currently accepted: Oligosiphonia with four pericentral cells and Polysiphonia with more than four. Diagnosis of Polysiphonia are: 1) prostrate and erect ecorticate axes with four pericentral cells; 2) branch initials separating at intervals of more than five segments; 3 ) lacking or rare vegetative trichoblasts; 4) rhizoids in open connection with pericentral cells; 5) procarps bearing a fourcelled carpogonial branch; 6) spermatangial branches arising directly from each axial cell; 7) tetrasporangia arranged in straight series on determinate branches and 8) apex is sharp-pointed.

In Myanmar, Kyi Win ${ }^{[3]}$ recorded 9 species Polysiphonia such as P. rhunensis Thur., P. spiralis Battens, $P$. insidiosa Crouan, $P$. foetidissima Cocks, $P$. variegate J.G. Agardh, P. Brodiaei Greville, P. harveyi Bailey, P. lanosa (Linn) Tandy and P. urceolata (Lightfoot) Greville. Kyaw Soe et $\mathrm{al}^{[4]}$ had also reported 9 species of Polysiphonia with the species $P$. sertularoides (Grateloup) J.Agardh instead of P. urceolata (Lightfoot) Greville. However, Kyaw Soe et $\mathrm{al}^{[4]}$ and Soe-Htun ${ }^{[5,6]}$ gave no specific description on Polysi-
Received date: July 27, 2015

Accepted date: Sep 06, 2015

Published date: Sep 10, 2015

Citation: Jar San., et al. Systematics of the Genus Polysiphonia Greville (Ceramiales, Rhodophyta) from Setse and Kyaikkhami Coastal Areas, Thanlwin River mouth, Myanmar. (2015) J Marine Biol Aquacult 1(1): 21-27.

phonia spp. due to lack of specimens mentioned in the previous reports, in the Department of Marine Science, Mawlamyine University, Myanmar (MMB). Recently, Soe-Htun et al ${ }^{[7,8]}$ listed two species of Polysiphonia, viz., P. subtilissima Montagne and $P$. sp. 1. Soe-Htun et al ${ }^{[9]}$ recorded the only species of $P$. subtilissima Montagne along Gwa coastal areas. Hlaing Hlaing Htoon ${ }^{[10]}$ reported the only species of Polysiphonia sp. 1. in Setse coastal areas. The purposes of this study are: 1) to identify the genus Polysiphonia Greville based on the morphology of vegetative and reproductive features; 2) to understand the biodiversity of Polysiphonia commonly found in Kyaikkhami and Setse coastal areas and 3) to know the distributional ranges of Polysiphonia Greville along the two Coastal Regions of Myanmar and the geo-

Copy rights: (C2015 Jar San. This is an Open access article distributed under the terms of Creative Commons Attribution 4.0 International License. 
graphical regions of the world oceans along with their potential uses.

\section{Materials and Methods}

The species of the genus Polysiphonia Greville were collected from the mangrove swamps and rocky shores in the upper intertidal zone of Setse (Lat.15 $52^{\prime} \mathrm{N}$, Long. 97 $35^{\circ} \mathrm{E}$ ) and Kyaikkhami (Lat. $16^{\circ} 05^{\prime} \mathrm{N}$, Long.97 $7^{\circ} 34^{\prime} \mathrm{E}$ ) coastal areas, Mon State during the period from June 2011 to March 2015. Fresh and living plants of specimens were fixed and preserved in $4 \%$ formaldehyde in seawater. Specimens have been identified with emphasis on the external and internal morphologies of vegetative and reproductive features. All voucher materials in the forms of wet-stack or herbarium specimens were deposited at the Herbarium of Department of Marine Science, Mawlamyine University, Myanmar (MMB). The sections were prepared by hand using double-edged razor blades. Vegetative structures such as thallus corticated or ecorticated, branching system, and formation of rhizoids and reproductive structures such as tetra sporangia, carpogonia were photographed using a Sony DSC-W 330 digital camera under compound and dissecting microscopes. Microscopic measurements were recorded in micrometer $(\mu \mathrm{m})$ using the ocular meter. Digital photographs processed by Adobe Photoshop CS3 were used in this study. The local and worldwide distributional ranges were based on the specimens housed in the Herbarium and literature available for the genus Polysiphonia Greville along with ecological notes of the plants. This study followed the classification system used by Guiry and Guiry ${ }^{[2]}$.

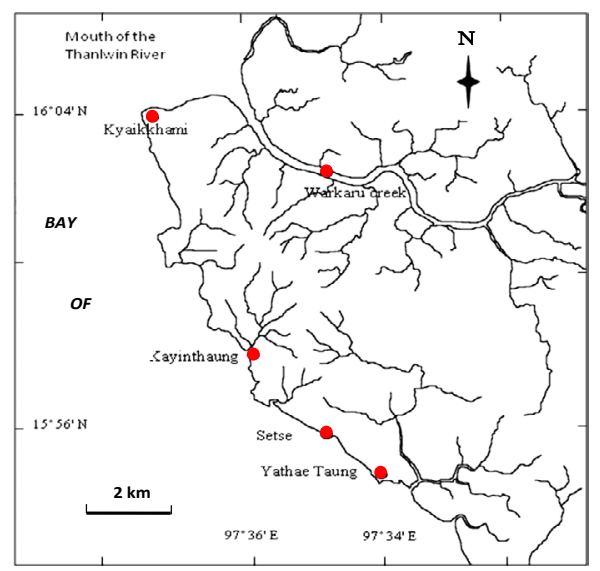

Figure 1: Map showing the collection sites of the samples.

\section{Results}

The two species of Polysiphonia: Polysiphonia subtilissima and $P$. sp 1 were collected from Setse and Kyaikkhami coastal areas.

\section{A Classification System of the Genus Polysiphonia}

Phylum: Rhodophyta

Class: Florideophyceae

Order: Ceramiales

Family: Rhodomelaceae

Genus: Polysiphonia Greville

Species: (1) Polysiphonia subtilissima Montagne (2) P. sp. 1

\section{Polysiphonia subtilissima Montagne (Figs. 2-18)}

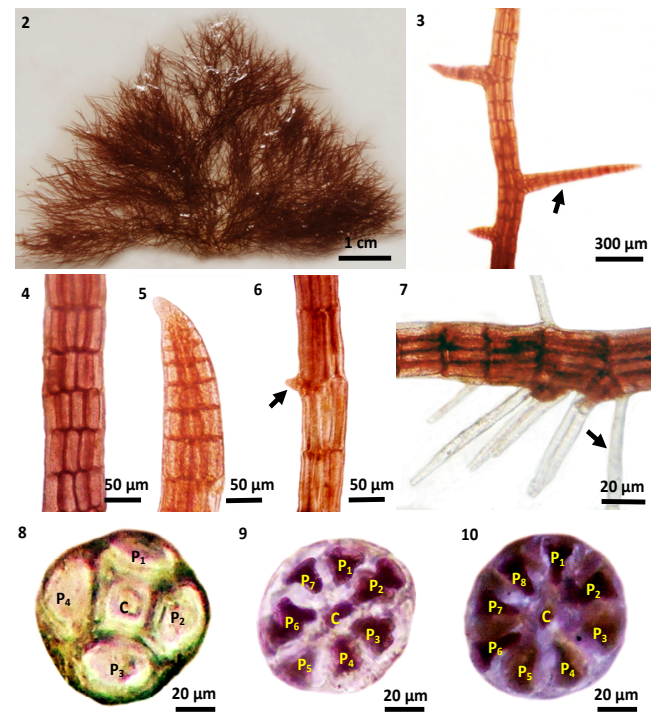

Figure 2-10: The external and internal structures of Polysiphonia subtilissima Montagne: 2) Vegetative plant; 3) Lateral branches (arrow) on erect branch; 4) Surface view of branch, showing elongated shaped cells; 5) Apex of a branch with rounded apical cells; 6) A little shoot (arrow) on lateral branch; 7) Unicellular rhizoids (arrow); 8) Cross section of erect branch showing central and 4 pericentral cells; 9) Cross section of lateral branches showing central and 7 pericentral cells; 10) Cross section of prostrate branches showing central and 8 pericentral cells. ${ }^{[11-19]}$

Type locality- Cayenne, French Guiana (Silva, Basson \& Moe 1996: 546).

Type- Herb. Montagne, PC (Womersley 2003:178) (as cited in Guiry and Guiry ${ }^{[2]}$ ).

\section{Vegetative Features}

External Features: Thallus up to $1-4 \mathrm{~cm}$ tall and $1-3 \mathrm{~cm}$ broad (Fig.2), soft, reddish brown, saxicolous; attached by scattered rhizoids (Fig.7) in open connection with the pericentral cells, usually one per segment, 45-100 $\mu \mathrm{m}$ diameter and 700-1500 $\mu \mathrm{m}$ long, providing with discoid heptra at creeping base; long erect branches arising from indistinct creeping base, 40-100 $\mu \mathrm{m}$ in diameter; lateral branches (Fig.3) arising at interval of 3-5 segments measured 40-60 $\mu \mathrm{m}$ long (Fig.4), in sub-alternate, with rounded apex (Fig.5), $50 \mu \mathrm{m}$ in diameter and $40 \mu \mathrm{m}$ long. A little shoot (Fig.6) arising from the erect branches and becoming a form of lateral branches.

Internal Features: Trichoblast poorly developed but rare, inconspicuous scar cells. In cross section of erect branches, pericentral cells 4 in number, ecorticated, 20-28 $\mu \mathrm{m}$ in length, thick walled and provided with pigments; central cell rectangular shape, about $20 \mu \mathrm{m}$ in length, thick walled and provided with pigments (Fig.8). Lateral branches are determinate and ecorticated, with 7 pericentral cells, 20-24 $\mu \mathrm{m}$ long, 20-24 $\mu \mathrm{m}$ broad, surrounding with a central cell, $18-20 \mu \mathrm{m}$ in diameter, thick walled and provided with pigments (Fig.9). The prostrate branch are ecorticated, with 8 pericentral cells, 20-24 $\mu \mathrm{m}$ long and 20-24 $\mu \mathrm{m}$ broad, surrounding with a central cell of 20-24 $\mu \mathrm{m}$ in diameter (Fig.10), cells are thick walled and provided with pigments.

Reproductive Structures: Tetrasporangial branches 1-7 cm 
tall and 1-5 cm broad, in long straight series in upper branchlets (Fig.11-12) and globe shape, 50-70 $\mu \mathrm{m}$ in diameter (Fig.13). The adventious initial cystocarp produced by lateral branches and main axis (Fig.15). Cystocarps are ovoid to globular and have a stalk consisting of a segment, 200-250 $\mu \mathrm{m}$ diameter, with ostiole 40-50 $\mu \mathrm{m}$ in diameter, carpospores $35-50 \mu \mathrm{m}$ in diameter (Fig.16) contains many clavate carpospores; surrounding with the gonimoblast filaments, 180-200 $\mu \mathrm{m}$ long (Fig.17). Spermatangial branches cylindrical, $130-150 \mu \mathrm{m}$ long and 25-50 $\mu \mathrm{m}$ broad with subtending trichoblast, sterile tips absent or consisting of 1-2 small cells (Fig.18). Thallus from discoid base, erect filaments subdichotomously branched, replacing trichoblasts in developments; deciduous, leaving conspicuous scar cells (Fig.14).

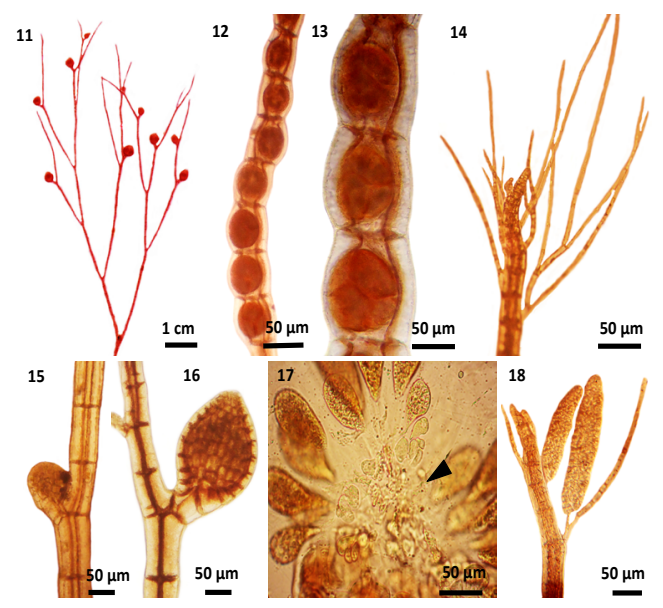

Figure 11-18: The reproductive structures of Polysiphonia subtilissima Montagne: 11) Carposporophyte plant; 12-13) Branch apex with tetrasporangia; 14) Branch arising in axils of trichoblasts; 15) Initial arise cystocarp; 16) Mature cystocarp; 17) A longitudinal section of mature cystocarp showing compact gonimoblast filaments (arrowhead); 18) Spermatangia ${ }^{[20-27]}$.

Specimens Examined of the Study Areas- Kyaikkami (Jar San, 13.viii. 2011; MMB 11065-11069: Vegetative plant; 13.ix.2011; MMB 11070-11073: Vegetative plant; 27.ix.2011; MMB 1107411080: Vegetative plant; 19.x.2011; MMB 11081-11086: Vegetative plant; 12.xii.2011; MMB 11597-11600: Vegetative plant; 10.i.2012; MMB 11601: Vegetative plant; 10.i.2012; MMB 11602: Spermatangial; 10.i.2012; MMB 11603: Trichoblast; 18.ii.2012; MMB 11604: Vegetative plant; 18.ii.2012; MMB 11605: Trichoblast; 18.ii.2012; MMB 11606: Tetrasporophyte; 18.ii.2012; MMB 11607-116010: Spermatangial; 18.ii.2012; MMB 11611-11615: Carposporophyte).

Other Specimens Examined- Kyaikkhami (Soe $\mathrm{Pa} \mathrm{Pa}$ Kyaw, 28.xiii.2004; MMB 10582: Vegetative plant; Soe-Htun, 28.xiii.2004; MMB 10583: Vegetative plant; Hlaing Hlaing Htoon, 28.xiii.2004; MMB 10584-10584: Vegetative plants; Third year Students of group IV, 4.vii.2010; MMB 10573; 7.viii.2010; MMB 10574: Vegetative plants; Soe Pa Pa Kyaw and Khin Khin Gyi, 7.vii.2010; MMB 10575: Vegetative plant; Thi Ha Aung, 7.viii.2010; MMB 10576: Vegetative plant; Hein Zaw, 7.viii.2010; MMB 10577: Vegetative plant; Naw Thein Thein Aye, 7.viii.2010; MMB 10578: Vegetative plant; Win Htet Naing, 7.viii.2010; MMB 10579: Vegetative plant; May Thu Aung, 7.viii.2010; MMB 10580: Vegetative plant; Mya Kyawt Wai, 14.viii.2010; MMB 10581: Tetrasporophyte; Sein
Moh Moh Khaing, 14.xii.2011; MMB 11195, 21.i.2012; MMB 11317, 11196, 31.i.2012; MMB 11250: Tetrasporophyte and Carposporophyte); Ei Ei Hlaing, 17.ii.2014; MMB 259.

Myanmar Distribution: Tanintharyi Coastal Region: Lampi I., High I, Kampani, Kawdut, Kalegauk, Setse, Kyaikkhami; Ayeyarwady Delta and Gulf of Mottama (Martaban) Coastal Region: No data; and Rakhine Coastal Region: Shwe Ya Gyaing, Hlyaw Gaung Taung, Maw Shwe Gyaing, Sin Pyu Gyaing.

World Distribution: Europe: Adriatic, Greece, Ireland, Italy, Spain; Atlantic Islands: Ascension, Bermuda, Cape Verde Islands, St Helena; North America: Florida, Georgia, Louisiana, Mississippi, New Hampshire, North Carolina, Texas, Virginia; Caribbean Islands: Bahamas, Barbados, Caribbean, Cayman Islands, Cuba, Jamaica, Lesser Antilles, Virgin Islands; South America: Brazil, Chile, Guyana, Uruguay, Venezuela; Africa: Angola, Cameroon, Cote d'Ivoire, Equatorial Guinea, Gambia, Ghana, Kenya, Liberia, Mauritius, Senegal, Sierra Leone, South Africa; Indian Ocean Islands: Aldabra Islands, Seychelles; Asia: Korea; South-east Asia: Philippines, Vietnam; South-east Asia: India, Levant States; Australia and New Zealand: New South Whales, New Zealand, Queensland, South Australia, Tasmania, Victoria, Western Australia; Pacific Island: Federated States of Micronesia, Hawaiian.

Ecological Notes: The vegetative plant of Polysiphonia subtilissima Montagne found from June 2011 to March 2015 during the collecting periods. This plant grows on muddy bottoms and various types of substrates of shallow pools and on the neumatophores of mangrove plants by means of unicellular rhizoids in the upper intertidal zone of Kyaikkhami Coastal Area. Associated algal species are Bostrychia tenella, Caloglossa bengalensis, Dictyota adnata, Hydropuntia edulis and Ulva compressa.

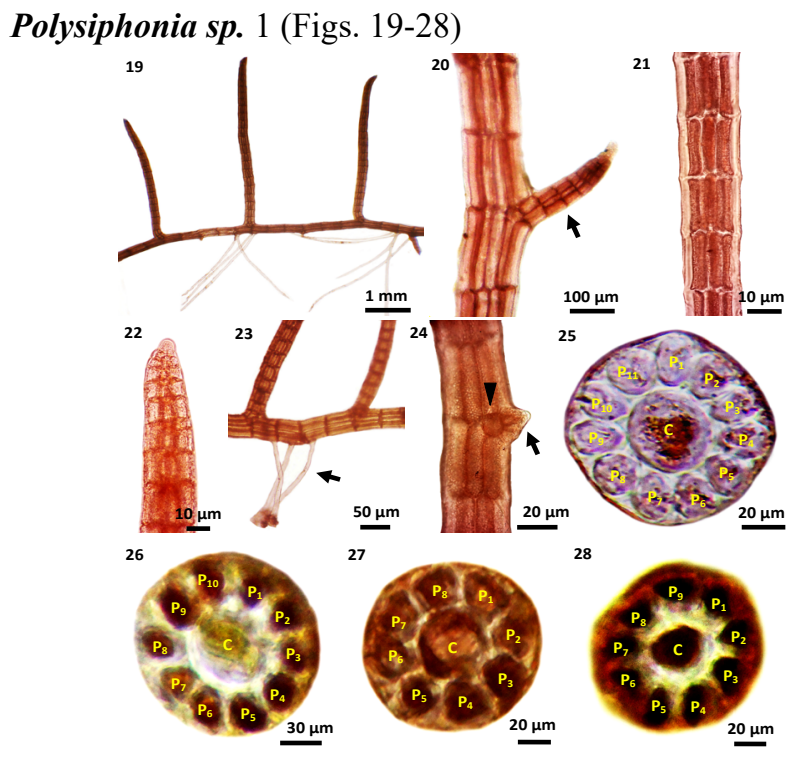

Figures 19-28: The external and internal structures of P. sp.1: 19) Vegetative plant; 20) Lateral branch (arrow) on erect branch; 21) Surface view of branch, showing elongated shaped cells; 22) Apex of branch with rounded apical cell; 23) Unicellular rhizoids (arrow) of P. sp.1; 24) A little shoot (arrow) on lateral branch, entire central cell (arrow head); 25) Cross section of erect branch showing central and 11 pericentral cells; 26) Cross section of lateral branch showing central and 10 pericentral cells; 27) Cross section of prostrate branch showing central 
and 8 pericentral cells; 28) Cross section of prostrate branch showing central and 9 pericentral cells ${ }^{[10,22,23,25,26]}$.

Type Locality- Unknown

Type- Unknown

\section{Vegetative Features}

External Features- Thallus up to 1-4 $\mathrm{mm}$ tall and 1-3 $\mathrm{mm}$ broad (Fig.19), rigid, slender, reddish brown in color, much branched; on the pneumatophores of mangrove plants attached by means of unicellular rhizoids (Fig.23) at the creeping base, rhizoid arising from pericentral cells, usually 2 or more segments, 10-40 $\mu \mathrm{m}$ diameter and 38-400 $\mu \mathrm{m}$ long, provided with discoid heptra at prostrate branch; short erect branches arising from distinct creeping base, 100-325 $\mu \mathrm{m}$ in diameter (Fig.20); lateral branches are alternate or secund in manner, the segment 100-120 $\mu \mathrm{m}$ long. Lateral branches (Fig.20) arising at intervals of 3-5 segments, measured 130-190 $\mu \mathrm{m}$ long and 40-50 $\mu \mathrm{m}$ broad (Fig.21). Apical cells are relatively prominent, acute (Fig.22). A little shoot (Fig.24) arising from the erect branches.

Internal Features- In the cross section of erect branches, 11 numbers in pericentral cells (Fig.25) ecorticated, 28-30 $\mu \mathrm{m}$ long $18-20 \mu \mathrm{m}$ broad, thick wall and provided with pigments. Central cell (Fig. 25) rounded $40 \mu \mathrm{m}$ in diameter, provided with pigments. In the cross section of lateral branches, pericentral cells are ecorticated, 10 in numbers, and 28-30 $\mu \mathrm{m}$ long and 20-24 $\mu \mathrm{m}$ broad, thick walled and provided with pigments. Central cell (Fig.26) rounded $32 \mu \mathrm{m}$ in diameter, thick walled and provided with pigments. In the cross section of prostrate branches, pericentral cells (Figs.27-28) are 8-9 in number, ecorticated, 24-40 $\mu \mathrm{m}$ long and 20-32 $\mu \mathrm{m}$ broad, thick walled and provided with pigments; central cell (Figs.27-28) rounded 24-32 $\mu \mathrm{m}$ in diameter, provided with pigments and thin walled.

Specimens Examined of the Study Areas- Setse (Jar San, 14.ix.2011; MMB 11091-11095: Vegetative plant; 14.ix.2011; MMB 11096-11098: Vegetative plant; Kyaikkhami: 12.xii.2011; MMB 11617-11620: Vegetative plant; 10.i.2012; MMB 1162111630: Vegetative plant; Setse: Jar San, 12.xii.2012; MMB 11631-11640: Vegetative plant; 10.i.2012; MMB 11641-11645: Vegetative plant; 18.ii.2012; MMB 11646-11650: Vegetative plant).

Other Specimens Examined- Setse (Third year students of group IV, 15.viii.2010: MMB 10567: Vegetative plant; Thi Ha Aung, 15.viii.2010: MMB 10568: Vegetative plant; Hein Zaw, 15.viii.2010: MMB 10569: Vegetative plant; Naw Thein Thein Aye, 15.viii.2010: MMB 10570: Vegetative plant; Wint Htet Naing, 15.viii.2010: MMB 10571: Vegetative plant; May Thu Aung, 15.viii.2010: MMB 10572: Vegetative plant; Kyaikkhami (Sein Moh Moh Khaing, 21.i.2011; MMB 11308, 11309).

Myanmar Distribution- Tanintharyi Coastal Region: Kampani, Kalegauk, Setse, Kyaikkhami;

Ayeyawady Delta and Gulf of Mottama (Martaban) Coastal Region: No data; and Rakhine Coastal Region: Gwa.

Ecological Notes- The vegetative plant of Polysiphonia sp.1 grow on various types of on muddy bottoms and attached on the pneumatophores of mangrove plants by means of unicellular rhizoid in upper intertidal zone of Setse. The vegetative plants are found from July to November during the collecting periods. Polysiphonia sp. 1 associated algal species are Caloglossa bengalensis, Bostrychia tenella and the species of Laurencia.

\section{Discussion}

The species of identification under the genus Polysiphonia Greville was carried out based on the morphological features such as habit and height of plant, texture, color, holdfast, branching patterns, presence or absence of axial cortication, number of transversely divided pericentral cells, shape and size of apical cells, segments interval and type of heptra, poly or monosiphonous of the lateral and reproductive features. In the present study, there were two species of the genus Polysiphonia Greville as Polysiphonia subtilissima Montagne and Polysiphonia sp.1.

A comparison of the taxonomic criteria in Polysiphonia species was shown in Table 1. The two species Polysiphonia grow in tuft, densely crowded, forming large aggregation usually on rocks or pneumatophores of mangroves trees. The specimens of $P$. subtilissima Montagne examined here are mostly similar to the description and illustrations given by Taylor ${ }^{[14]}$ and Yoon ${ }^{[17]}$. The specimen of the present study were rather soft in texture as described by Taylor ${ }^{[14]}$ whereas those were fragile in Yoon's ${ }^{[17]}$ description.

Table 1: A comparison of the taxonomic criteria in Polysiphonia species from Setse and Kyaikkhami coastal areas.

\begin{tabular}{|c|c|c|c|}
\hline \multicolumn{2}{|r|}{ Characters } & $\begin{array}{l}\text { P. subtilissima } \\
\text { Montagne }\end{array}$ & P. sp. 1 \\
\hline \multicolumn{4}{|c|}{ I. Vegetative structures: } \\
\hline \multirow{7}{*}{$\begin{array}{l}\text { 1. Habit of } \\
\text { plant }\end{array}$} & (a) Erect & - & - \\
\hline & (b) Prostrate & $\begin{array}{l}\text { Prostrate with } \\
\text { long erect } \\
\text { branch }\end{array}$ & $\begin{array}{l}\text { Prostrate with short } \\
\text { erect branch }\end{array}$ \\
\hline & (c) Substratum & Saxicolous & $\begin{array}{c}\text { Pneumatophores of } \\
\text { mangrove plant }\end{array}$ \\
\hline & (d) Height of plant & $1-4 \mathrm{~cm}$ & $1-4 \mathrm{~mm}$ \\
\hline & (e) Diameter of plant & $1-3 \mathrm{~cm}$ & $1-3 \mathrm{~mm}$ \\
\hline & (f) Color & Reddish brown & Reddish brown \\
\hline & (g) Texture & Soft & Rigid \\
\hline \multirow{3}{*}{$\begin{array}{l}2 . \\
\text { Holdfast }\end{array}$} & (a) Type & $\begin{array}{l}\text { Unicellular with } \\
\text { discoid base }\end{array}$ & $\begin{array}{l}\text { Unicellular with } \\
\text { discoid base }\end{array}$ \\
\hline & (b) Length & $700-1500 \mu \mathrm{m}$ & $38-400 \mu \mathrm{m}$ \\
\hline & (c) Width & 45-100 $\mu \mathrm{m}$ & $10-40 \mu \mathrm{m}$ \\
\hline \multirow{4}{*}{$\begin{array}{c}3 . \\
\text { Branches }\end{array}$} & (a) Branching type & Sub-alternate & Secund \\
\hline & (b) Apical cells & & \\
\hline & (i) Size & $50 \mu \mathrm{m}$ & \\
\hline & (ii) Shape & Round & Acute \\
\hline \multicolumn{4}{|c|}{ II. Internal structures: } \\
\hline \multirow{3}{*}{$\begin{array}{c}1 . \\
\text { Cross } \\
\text { section } \\
\text { of erect } \\
\text { branch }\end{array}$} & $\begin{array}{l}\text { (a) Corticated or } \\
\text { ecorticated }\end{array}$ & Ecorticated & Ecorticated \\
\hline & $\begin{array}{c}\text { (b) No. of pericentral } \\
\text { cells }\end{array}$ & 4 & 11 \\
\hline & $\begin{array}{l}\text { (c) Diameter of } \\
\text { central cell }\end{array}$ & $20 \mu \mathrm{m}$ & $40 \mu \mathrm{m}$ \\
\hline
\end{tabular}




\begin{tabular}{|c|c|c|c|}
\hline \multirow{5}{*}{$\begin{array}{l}\text { 2. Cross } \\
\text { section } \\
\text { of lateral } \\
\text { branch }\end{array}$} & (a) Diameter & & \\
\hline & $40-60 \mu \mathrm{m}$ & $100-120 \mu \mathrm{m}$ & \\
\hline & $\begin{array}{l}\text { (b) Corticated or } \\
\text { ecorticated }\end{array}$ & Ecorticated & Ecorticated \\
\hline & $\begin{array}{c}\text { (c) No. of pericentral } \\
\text { cells }\end{array}$ & 7 & 10 \\
\hline & $\begin{array}{l}\text { (d) Diameter of } \\
\text { central cell }\end{array}$ & $18-20 \mu \mathrm{m}$ & $32 \mu \mathrm{m}$ \\
\hline \multirow{3}{*}{$\begin{array}{l}\text { 3. Cross } \\
\text { section of } \\
\text { prostrate } \\
\text { branch }\end{array}$} & $\begin{array}{l}\text { (a) Corticated or } \\
\text { ecorticated }\end{array}$ & Ecorticated & Ecorticated \\
\hline & $\begin{array}{c}\text { (b) No. of pericentral } \\
\text { cells }\end{array}$ & 8 & $8-9$ \\
\hline & $\begin{array}{l}\text { (c) Diameter of } \\
\text { central cell }\end{array}$ & $20-24 \mu \mathrm{m}$ & $24-32 \mu \mathrm{m}$ \\
\hline
\end{tabular}

Undersides of the thallus are usually prostrate while the growing species are commonly curved with the concavity towards the substratum. Many of the lateral branches are of limited growth, arising in longitudinal rows. A newly recorded species of Polysiphonia as $P$. sp.1 resembles $P$. subtilissima Montagne because the branches of the plant are reddish brown in color and growing in upper intertidal zone. They are lacking of cortication and are entirely polysiphonous branches. P. subtilissima Montagne has similarity with the plant of $P . s p .1$; both have ecorticated, reddish brown color and growing on pneumatophores of mangrove plants and muddy bottom. P. subtilissima was 1-4 cm tall and soft plant but $P$. sp.1 was $1-4 \mathrm{~mm}$ and rigid plant. Moreover, P.subtilissima attach by scattered rhizoids in open connection with the pericentral cells, usually one per segment. These results are similar with Womersley ${ }^{[1]}$ and Yoon ${ }^{[17]}$ mentioned for that species. In addition, Guiry (2010) mentioned that P. subtilissima Montagne is currently regarded as a synonym of P. subtilissima var. westpointensis Harvey (1853) and P. angustissima Kützing (1864).

P. subtilissima Montagne was 45-100 $\mu \mathrm{m}$ diameter and 700-1500 $\mu \mathrm{m}$ long while in P. sp. 1 was $10-40 \mu \mathrm{m}$ diameter and $38-400 \mu \mathrm{m}$ long, provided with discoid heptra at creeping base. In $P$. sp.1, lateral branches secund of in manner, the segments are $100-120 \mu \mathrm{m}$ in long but the plants of $P$. subtilissima Montagne, lateral branches arising at interval of 3-5 segment measured 40$60 \mu \mathrm{m}$ long, in sub-alternate. P. subtilissima Montagne exhibited rounded apex, $50 \mu \mathrm{m}$ in diameter and $40 \mu \mathrm{m}$ long while the plant of $P$. sp. 1 was growing apex acute. These results agree with Yoon $^{[17]}$ and Womersley ${ }^{[28]}$. The two species have short shoot arising from the erect branches and this shoot gives rise to the lateral branches.

Among the two species of Polysiphonia, the larger size of plants measured up to $1-4 \mathrm{~cm}$ tall and $1-3 \mathrm{~cm}$ broad is found in $P$. subtilissima Montagne while the smaller plant of $P$. sp. 1 is 1-3 mm tall. Erect branches ecorticated and 4 pericentral cells enclosed a central cell of about $20 \mu \mathrm{m}$ diameter in P. subtilissima Montagne while in P. sp.1, the central cell, $40 \mu \mathrm{m}$ in diameter, was surrounded by 11 pericentral cells and provided with pigments. Branches are composed of a polysiphonous axes. Lateral branches ecorticated and composed of central axial cell, 18-20 $\mu \mathrm{m}$ in diameter, surrounded by 7 pericentral cells in P. subtilissima Montagne and 10 pericentral cells surround a central cell, $32 \mu \mathrm{m}$ in diameter as in $P$. sp. 1 and provided with pigments. The prostrate branches, which have a central axial cell of 20-24 $\mu \mathrm{m}$ in diameter bounded by 8 pericentral cells and ecorticated in $P$.

subtilissima

Montagne while in $P . s p .1,8-9$ pericentral cells surrounded a central cell, $24-32 \mu \mathrm{m}$ in diameter, provided with pigments.

Polysiphonia are widely distributed from tropical to warm temperate seas throughout the world. There are 993 species (and infraspecific) names in the database at present, of which 193 have been flagged as currently accepted taxonomically. Dawson ${ }^{[13]}$ stated 4 species of under the genus of Polysiphonia such as $P$. fragilis Suringar, $P$. subtilissima Montagne, $P$. tongatensis Harvey and $P$. coacta Tseng from the Pacific region. Taylor $^{[14]}$ listed 18 species of the genus Polysiphonia, from the Eastern tropical and subtropical coasts of the Americas.

Cordero $^{[16]}$ studied 7 species of Polysiphonia such as $P$. forcipata Harvey, P. howei Hollenberg, P. mollis Hooker et Harvey, $P$. setacea Hollenberg, $P$. subtilissima Montagne, $P$. tepida Hollenberg and P. upblensis (Grun.) Hollenberg were collected from Philippine marine red algae. Womersley ${ }^{[1]}$ studied 26 species under the genus Polysiphonia including the $P$. subtilissima Montagne from Southern Australia. Yoon ${ }^{[17]}$ investigated that the 20 species of a taxonomic study of genus Polysiphonia from Korea and it was considered $P$. subtilissima Montagne. Silva et $\mathrm{al}^{[20]}$ also listed the species $P$. subtilissima Montagne under the genus Polysiphonia Greville from benthic marine algae of the Philippines.

In $P$. subtilissima plant, tetrasporangial branches can be observed in long straight series in upper branchlets and are globe shape. Cystocarps are ovoid to globular and have a stalk consisting of a segment, 200-250 $\mu \mathrm{m}$ diameter, with ostiole 40-50 $\mu \mathrm{m}$ in diameter, carpospores $35-50 \mu \mathrm{m}$ in diameter, contains many clavate carpospores, surround with the gonimoblast filament $180-200 \mu \mathrm{m}$ long. Yoon ${ }^{[17]}$ and Womersley ${ }^{[28,1]}$ also reported similar results.

Spermatangial branches are cylindrical, 130-150 $\mu \mathrm{m}$ long and $25-50 \mu \mathrm{m}$ broad, with subtending trichoblast sterile tips absent or constitute 1-2 small cells. Yoon ${ }^{[17]}$ described spermatangial branches, replacing whole trichoblast, lanceolate, 150-300 $\mu \mathrm{m}$ in length, 40-70 $\mu \mathrm{m}$ in width, with 3-5 celled sterile tips. Womersley ${ }^{[28,1]}$ also described the spermatangial branches were measuring $150-300 \mu \mathrm{m}$ in length and $30-65 \mu \mathrm{m}$ in width. The spermatangia of $P$. subtilissima Montagne are similarly like to that of $P$. acuminata Gardh. Likewise, the cystocarps of $P$. subtilissima Montagne are nearly as same as that of $P$. savatieri Har. in morphology. In this study, trichoblast are rarely observed in fresh specimens, although conspicuous scar cells are mostly found as described by Yoon ${ }^{[17]}$ Womersley $^{[28,1]}$ described spermatangial branches were 200-350 $\mu \mathrm{m}$ long and 45-65 $\mu \mathrm{m}$ in width, replacing the whole trichoblast and with a sterile tip 4-6 cell long. During the studying period, reproductive structures were not found in the plants of $P$. sp. 1 whereas the plants of $P$. subtilissima Montagne possessed several tetrasporangia at the tip of the branches and have many mature and immature cystocarps.

In Myanmar, Kyi Win ${ }^{[3]}$ recorded 9 species of the genus Polysiphonia such as $P$. rhunensis Thur., P. spiralis Battens, $P$. insidiosa Crouan, $P$. foetidissima Cocks, $P$. variegate J.G. Agardh, $P$. brodiaei Greville, $P$. harveyi Bailey, P. lanosa (Linn) Tandy and $P$. urceolata (Lightfoot) Greville. Moreover, Kyaw Soe et $\mathrm{al}^{[4]}$ had also described 9 species of Polysiphonia with the species $P$. sertularoides (Grateloup) J. Agardh instead of former- 
ly recorded $P$. urceolata (Lightfoot) Greville. Soe-Htun et al ${ }^{[29]}$ and Soe-Htun et a ${ }^{[5]}$ gave no specific identification on Polysiphonia spp. due to lack of specimens mentioned in the previous reports. Hlaing Hlaing Htoon ${ }^{[10]}$ reported the only species of $P$. $s p .1$ in Setse coastal areas. Soe-Htun et al ${ }^{[8]}$ listed two species of Polysiphonia, viz., P. subtilissima Montagne and $P$. sp.1. SoeHtun et al ${ }^{[9]}$ recorded the only species of $P$. subtilissima Montagne along Gwa coastal areas.

In the present study, the genus Polysiphonia Greville reveals the latitudinal distribution along the two Coastal Regions, based on the specimens examined (Fig.29, Table2). P. subtilissima Montagne distributes along the Tanintharyi Coastal Region from Lampi Island (Lat. $10^{\circ} 58^{\prime} \mathrm{N}$, Long. $98^{\circ} 08^{\prime} \mathrm{E}$ ) to Kyaikkhami (Lat. $16^{\circ} 05^{\prime} \mathrm{N}$, Long. 97 $34^{\prime} \mathrm{E}$ ); Ayeyawady Delta and Gulf of Martaban Coastal Region: No data; and along the Rakhine Coastal Region from Shwe Ya Gyaing (Lat. 17 $37^{\prime} \mathrm{N}$, Long. 94 $34^{\prime} \mathrm{E}$ ) to Sin Phyu Gyaing (Lat. $18^{\circ} 10^{\prime} \mathrm{N}$, Long.

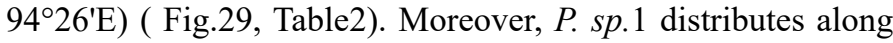
the Tanintharyi Coastal Region from Kampani (Lat. $14^{\circ} 02^{\prime} \mathrm{N}$, Long. $98^{\circ} 04^{\prime} \mathrm{E}$ ) to Kyaikkhami (Lat. $16^{\circ} 05^{\prime} \mathrm{N}$, Long. $97^{\circ} 34^{\prime} \mathrm{E}$ ); the Ayeyawady Delta and Gulf of Martaban Coastal Region: No data; and the Rakhine Coastal Region in Gwa coastal area (Lat. $17^{\circ} 37^{\prime} \mathrm{N}$, Long. $94^{\circ} 34^{\prime} \mathrm{E}$ ).

Table 2: The distributional range of Polysiphonia subtilissima Montagne and $\mathrm{P}$. sp.1 along three Coastal Regions of Myanmar.

\begin{tabular}{|c|c|c|c|c|c|c|c|}
\hline \multirow{3}{*}{$\begin{array}{l}\text { Sr. } \\
\text { No. }\end{array}$} & \multirow{3}{*}{$\begin{array}{l}\text { Spe- } \\
\text { cies }\end{array}$} & \multicolumn{6}{|c|}{ Coastal Regions } \\
\hline & & \multicolumn{2}{|c|}{ TCR } & \multicolumn{2}{|c|}{ ACR } & \multicolumn{2}{|c|}{ RCR } \\
\hline & & From & To & From & To & From & To \\
\hline 1 & $\begin{array}{l}P . \\
\text { sub- } \\
\text { tilis- } \\
\text { sima } \\
\text { Mon- } \\
\text { tagne }\end{array}$ & $\begin{array}{l}\text { Lampi } \\
\text { Island } \\
\text { (Lat. } 10^{\circ} \\
58^{\prime} \mathrm{N}, \\
\text { Long. } 98^{\circ} \\
08^{\prime} \mathrm{E} \text { ) }\end{array}$ & $\begin{array}{l}\text { Kyaik- } \\
\text { khami } \\
\text { (Lat. } 16^{\circ} \\
05^{\prime} \mathrm{N}, \\
\text { Long. } 97^{\circ} \\
33^{\prime} \mathrm{E} \text { ) }\end{array}$ & $\begin{array}{l}\text { No } \\
\text { data }\end{array}$ & $\begin{array}{l}\text { No } \\
\text { data }\end{array}$ & $\begin{array}{l}\text { Shwe Ya } \\
\text { Gyaing } \\
\text { (Lat. } 17^{\circ} \\
37^{\prime} \mathrm{N}, \\
\text { Long. } 94^{\circ} \\
\left.34^{\prime} \mathrm{E}\right)\end{array}$ & $\begin{array}{l}\text { Sin Phyu } \\
\text { Gyaing } \\
\text { (Lat. } 18^{\circ} \\
10^{\prime} \mathrm{N}, \\
\text { Long. } 94^{\circ} \\
26^{\prime} \mathrm{E} \text { ) }\end{array}$ \\
\hline 2 & $\begin{array}{l}\text { Poly- } \\
\text { sip- } \\
\text { honia } \\
\text { sp. } 1\end{array}$ & $\begin{array}{l}\text { Kampani } \\
\text { (Lat. } 14^{\circ} \\
02^{\prime} \mathrm{N}, \\
\text { Long. } 98^{\circ} \\
04^{\prime} \mathrm{E} \text { ) }\end{array}$ & $\begin{array}{l}\text { Kyaik- } \\
\text { khami } \\
\text { (Lat. } 16^{\circ} \\
05^{\prime} \mathrm{N}, \\
\text { Long. } 97^{\circ} \\
34^{\prime} \mathrm{E} \text { ) }\end{array}$ & $\begin{array}{l}\text { No } \\
\text { data }\end{array}$ & $\begin{array}{l}\text { No } \\
\text { data }\end{array}$ & $\begin{array}{l}\text { Gwa } \\
\text { (Lat. 17 } \\
37^{\prime} \mathrm{N} \text {, } \\
\text { Long. } \\
\left.94^{\circ} 34^{\prime} \mathrm{E}\right)\end{array}$ & No data \\
\hline
\end{tabular}

Abbreviations: $\mathrm{RCR}=$ The Rakhine Coastal region; ACR $=$ The Ayeyawady Delta and Gulf of Mottama (Martaban) Coastal region; TCR $=$ The Tanintharyi Coastal region.

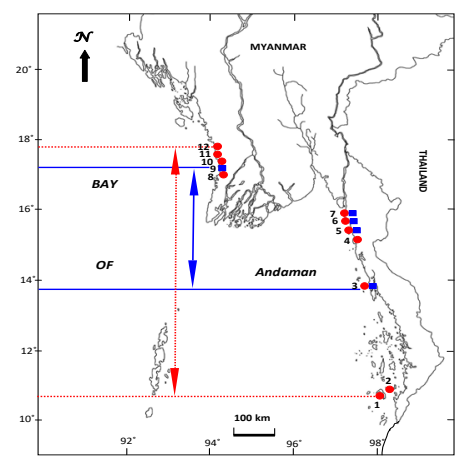

Figure 29: Distribution of $P$. subtilissima Montagne and $P$. sp. 1 along the three coastal regions of Myanmar. 1. Lampi I., 2. High I, 3. Kampani, 4. Kawdut, 5. Kalegauk, 6. Setse, 7. Kyaikkhami, 8. Shwe Ya Gyaing, 9. Gwa, 10. Hlyaw Gaung Taung, 11. Maw Shwe Gyaing, 12. Sin Phyu Gyaing, Symbols: - P. subtillissima Montagne, - P. sp 1, $\longrightarrow$ Distribution range of $P$. subtillissima Montagne and $\longmapsto$ Distribution range of $P$. sp.1.
With regard to phytogeographical distribution, $P$. subtilissima Montagne is widely distributed in tropical and temperate coasts of Atlantic Ocean, Indian Ocean and Pacific Ocean Regions (Fig.30). The distribution range of $P$. subtilissima Montagne is from Ireland as the northernmost recorded limit in the Atlantic Ocean to New Zealand as southernmost recorded limit in the Pacific Ocean. In general, this species mainly dominates in the Atlantic Ocean Regions.

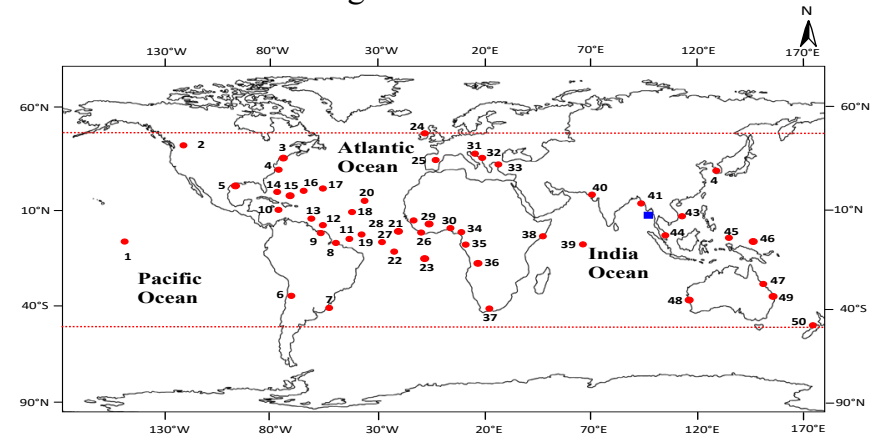

Figure 30: The worldwide distribution of Polysiphonia subtillissima Montagne and P. sp.1. 1. Hawaiian Islands, 2. Virginia, 3. North Carolina, 4. Georgia, 5. Texas, 6. Chile, 7. Uruguay, 8. Brazil, 9. Guyana, 10. Jamaica, 11. Trinidad, 12. Venezuela, 13. Caribbean, 14. Florida, 15. Cuba, 16. Bahamas, 17. Bermuda, 18. Virgin Islands, 19. Barbados, 20. Martinique, 21. Lesser Antilles, 22. Cape Verde Islands, 23. Asscension, 24. Ireland, 25. Spain, 26. Liberia, 27. Gambia, 28. Sierra Leone, 29. Senegal, 30. Ghana, 31. Italy, 32. Adriatic, 33. Greece, 34. Cameroon, 35. Equatorial Guinea, 36. Angola, 37. South Africa, 38. Kenya, 39. Seychelles, 40. India (Guiry 2010), 41. Myanmar (Soe-Htun et al. 2009a, b), 42. Korea, 43. Vietnam (Guiry 2010), 44. Malaysia (Phang 2006), 45. Philippines (Silva et al. 1987, Guiry 2010), 46. Federated States of Micronesia, 47. South Australia, 48. Western Australia, 49. Queensland, 50. New Zealand (Guiry and Guiry 2015). Symbols: $\bullet$ P. subtillissima Montagne, - P. sp.1; Northernmost and southernmost recorded limits.

\section{Conclusion}

Two species of Polysiphonia such as P. subtilissima Montagne and $P$. sp. 1 were identified from Setse and Kyaikkhami coastal areas of Mon State. The Polysiphonia species were identified by using branching patterns, presence or absent of axial cortication, number of pericentral cells and type of holdfast, polysiphonous or monosiphonous and reproductive features. Further studies are still needed to verify and revise the taxonomy of the genus Polysiphonia from Myanmar.

\section{Key to the Species of Polysiphonia from Setse and Kyaikkha- mi Coastal Areas}

1. Plant soft; up to $1-4 \mathrm{~cm}$ tall, creeping portion indistinct with long erect branches 40-100 $\mu \mathrm{m}$ diameter; branches sub-alternate; central cell small, surround by $4-8$ pericentral cells, apex is round, simple or bifid.

\section{P. subtilissima}

1. Plant rigid; about 1-4 mm tall, creeping portion distinct with short erect branches 100-325 $\mu \mathrm{m}$ in diameter; branches alternate or secund, central cell large, surrounded by $9-11$ pericentral cells, apex is mostly acute.

\section{P. sp. 1}




\section{Acknowledgement}

We are thankful to Dr. Aung Myat Kyaw Sein, Rector of Mawlamyine University and Dr. Zaw Win, Pro-Rector of Mawlamyine University, for their encouragement and support in preparing this work. We are deeply indebted to Dr. Min-Thein, Chairman, June Pharmaceutical Ltd., General Manager (Retd), Myanmar Spirulina Factory, Sagaing and Professor (Part-time), Department of Botany, University of Mandalay, for his valuable suggestions and constructive criticism on this study, and literature provided. We would like to thank Dr. San Tha Tun, Professor and Head of Department of Marine Science, Mawlamyine University for providing the departmental facilities. We would like to express our sincere thanks to the staffs of Setse Aquaculture Research Center who kindly help us in many ways during our field trips. Special thanks go to Dr. Soe $\mathrm{Pa} P a$ Kyaw and Dr. Mya Kyawt Wai, Assistant Lecturers, Department of Marine Science, Mawlamyine University, for their helpful assistance during this work. Many thanks go to Daw Khin Khin Gyi, Daw Sein Moh Moh Khaing and U Myo Min Tun, Demonstrators of the Department of Marine Science, Mawlamyine University. The first author, Daw Jar San would like to thank her beloved parents, U Naw Sant and Daw Zone Lwi for their physical, moral and financial supports made to reach the goal of this work. Funding for this work from the Ministry of Education and the Department of Marine Science, Mawlamyine University is most appreciated.

\section{References}

1. Womersley, H.B.S. Southern Australian species of Polysiphonia Greville (Rhodophyta). (1979) Aust J Bot 27(4): 459-528. 2. Guiry, M.D., Guiry, G.M. World-wide electronic publication, National University of Ireland, Galway. (2014) AlgaeBase.

3. Kyi, Win. A classified list of the seaweeds of Burma. (1972) Proceedings of the Burma Research Congress 25-29.

4. Kyaw Soe., Kyi-Win. Seaweeds for utilization. (1977) University Translation and Publication Department. Publication. 2(168): 502 pp (in Myanmar).

5. Soe-Htun, U. The seaweed resources of Myanmar. In: Critchley, A.T., Ohno, M., (Eds). Seaweed resources of the world. (1998) Kanagawa International Fisheries Training Centre Japan International Cooperation Agency (JICA) 99-105.

6. Soe-Htun, U. Distribution and potential uses of marine algae found along the coastal regions of Myanmar. (2005) Department of Marine Science Mawlamyine University Technical Report 5. 7. Soe-Htun, U., Mu Aye, M., Soe Kyaw, P., et al. Distribution and potential uses of marine algae found along the three coastal regions of Myanmar. (2007) Department of Marine Sciecnce Mawlamyine University Tech Rep 190 .

8. Soe-Htun, U., Mu Aye, M., Soe Kyaw, P., et al. Checklist, distribution and potential utilization of marine algae of Myammar II: Rhodophyta (Red Algae). (2009a) Journal of Myanmar Academy of Arts and Science 7(5): 279-305.

9. Soe-Htun, U., Mu Aye, M., Soe Kyaw, P., et al. Notes on some marine benthic red algae of Gwa coastal Areas II: Rhodophyta(Cryptonemiales, Gigartinales, Gracilariales, Rhodomeniales and Ceramials). (2009b) Journal of Myanmar Academy of Arts and Science 7(5): 143-181.

10. Htoon, H.H. Studies on the marine algae of Setse coastal areas. (2009) Unpublished Master of Research Thesis. Department of Marine Science. Mawlamyine University, Myanmar.

11. Kützing, F.T. Tabulae phycologicae. 1845-69a 1-6.

12. Kützing, F.T. Tabulae phycologicae. 1845-69b 7-19.

13. Dawson, E.Y. A quarterly devoted to the biological and physical sciences of the Pacific Region. (1954) Pacific Science University of Hawaii Press 3: 482.

14. Taylor, W.R. Marine algae of the eastern tropical and subtropical coast of the Americas. (1960) University of Michigan Press 870 .

15. Hoang Ho, P. Marine algae of South Vietnam. (1969) Saigon Study Centre 588 .

16. Cordero, P.A. Studies on the Philippine marine red algae. (1977) Special Publ Seto Marine Biol Lab Series 4 (632).

17. Yoon, H.Y. A taxonomic study of genus Polysiphonia (Rhodophyta) from Korea. (1986) ALGAE 1(1): 3-86.

18. Kudo, T., Masuda, M.. A taxonomic study of Polysiphonia japonica Harvey and P. akkeshiensis Segi (Rhodophyta). (1986) Jap J Phycol (Sôrui) 34: 293-310.

19. Young, D.N., Kapraun, D.F. The genus Polysiphonia (Rhodophyta, Ceramiales) Santa Catalina Island, California. (1985) Jap J Phycol (Sorui) 33: 103-117.

20. Silva, P.C., Menez, E.G., Moe, R.L. Catalogue of the benthic marine algae of the Philippines. (1987) Smithsonian Contributions to the Marine Sciences 27: 179.

21. Ortega, M., Godinez, J.L., Garduno, G. Catalogo de algas bentica de las castas Mexicanas del Golfo de Mexico y Mar Caribe. (2001) Universidad Nocional para el Conocimiento y Uso de la Biodiversisdad 594.

22. Jar San. The morphology and spore germination of the genus Polysiphonia Greville (Ceramiales, Rhodophyta) from Setse and Kyaikkhami coastal areas. (2012) Mawlamyine University Myanmar. (unpublished).

23. Sein Khaing, M.M. Studies on marine benthic algae of Kyaikkhami coastal areas. (2012) Mawlamyine University Myanmar. (unpublished).

24. Zayar, Aung. Study on the marine benthic red algae of Kampani coastal areas. (2012) Mawlamyine University Myanmar. (unpublished).

25. Myo, M.T. The floras and ecology of macrobenthic marine algae in Kampani coastal areas. (2013) Mawlamyine University Myanmar. (unpublished).

26. Thet, H.A. A study on the benthic algal flora of Kalegauk Island. (2013) Mawlamyine University Myanmar. (unpublished). 27. Hlaing. E.E. A study on the marine benthic red algae in Kawdut coastal areas Ye Township Mon State. (2014) Mawlamyine University Myanmar. (unpublished).

28. Womersley, H.B.S. The marine benthic flora of Southern Australia. Rhodophyta- Part III D. Ceramiales- Delesseriaceae, Sacromeniaceae, Rhodomelaceae. (1968) the University of Adelaide South Australia 533.

29. Soe-Htun, U., Hla Tint, U., San Tha Tun, U., et al. A review on the seaweed research in Myanmar. (1997) Department of Marine Science Mawlamyine University Tech Rep 27. 